Supporting Information

\title{
Amplification-Free DNA Sensor for the One-Step Detection of the Hepatitis B Virus Using an Automated Paper-Based Lateral Flow Electrochemical Device
}

Chawin Srisomwat, ${ }^{\dagger}$ Abdulhadee Yakoh, ${ }^{\dagger}$ Natthaya Chuaypen,, Pisit Tangkijvanich, ${ }^{\S}$ Tirayut Vilaivan ${ }^{\ddagger}$ Orawon

Chailapakul, ${ }^{\dagger}$ *

†Electrochemistry and Optical Spectroscopy Center of Excellence (EOSCE), Department of Chemistry, Faculty of Science, Chulalongkorn University, Pathumwan, Bangkok, 10330, Thailand

$\S$ Center of Excellence in Hepatitis and Liver Cancer, Department of Biochemistry, Faculty of Medicine, Chulalongkorn University, Pathumwan, Bangkok, 10330, Thailand

$\ddagger$ Organic Synthesis Research Unit, Department of Chemistry, Faculty of Science, Chulalongkorn University, Pathumwan, Bangkok, 10330, Thailand 


\section{Table of contents}

\section{Contents}

DNA sequences used in this study (mismatched bases are indicated by underline) (Table S1)

Comparison with the previous electrochemical approach for HBV DNA detection (Table S2)

Synthesis of acpcPNA Probe

Mass spectrum of the acpcPNA (Figure S1)

Chromatogram for confirming the purity of acpcPNA (Figure S2)

Materials, Equipment, and Chemicals

Serum Extraction of HBV DNA using phenol-chloroform-isoamyl alcohol method

Plasmid constructs HBV DNA preparation

Component of the automated paper-based lateral flow device (Figure S3)

Amperometric response of ascorbic acid (Figure S4)

Flow velocity at different channel widths (Figure S5)

The effect of type of surfactants (Figure S6)

Stability of automated eFLA device (Figure S7)

The feasibility of the proposed device with the HBV DNA plasmid constructs (Figure S8) 
Table S1. DNA sequences used in this study (mismatched bases are indicated by underline)

\begin{tabular}{|c|c|}
\hline Name & Sequence (5' to 3') \\
\hline Complementary target DNA & CCT CTA ATT CCA GGA \\
\hline Single-base mismatch DNA & CCT CTA ATCE CCA GGA \\
\hline Two-base mismatch DNA & CCG CTA ATㅌ CCA GGA \\
\hline $\mathrm{HCV}$ cDNA & 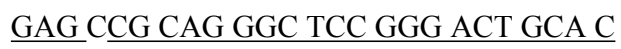 \\
\hline HPV DNA & $\underline{\text { GCT GGA GGT GTA TG }}$ \\
\hline
\end{tabular}


Table S2. Comparison with the previous electrochemical approach for HBV DNA detection

\begin{tabular}{|c|c|c|c|c|c|c|c|}
\hline Electrode & Detection system & Probe & $\begin{array}{l}\text { Labelling } \\
\text { approach }\end{array}$ & Linear range & Limit of detection & Analysis time & Ref. \\
\hline $\begin{array}{l}\text { Carbon stencil paper } \\
\text { electrode }\end{array}$ & ASV & DNA & AgNPs & $0-500 \mathrm{pM}$ & $85 \mathrm{pM}$ & $35 \mathrm{~min}$ & 1 \\
\hline $\begin{array}{l}\mathrm{Cu}_{3}\left(\mathrm{PO}_{4}\right)_{2} \text {-BSA- } \\
\mathrm{GO} / \mathrm{Au} \text { electrode }\end{array}$ & DPV & DNA & Ferocene & $\begin{array}{c}1.10 \times 10^{3}-1.21 \times 10^{5} \text { copies } \\
\mathrm{mL}^{-1}\end{array}$ & 1100 copies $\mathrm{mL}^{-1}$ & $120 \mathrm{~min}$ & 2 \\
\hline GQDs/GCE & DPV & DNA & Label-free & $10-500 \mathrm{nM}$ & $1 \mathrm{nM}$ & $30 \mathrm{~min}$ & 3 \\
\hline $\begin{array}{l}\text { Graphene screen- } \\
\text { printed paper } \\
\text { electrode }\end{array}$ & DPV & acpcPNA & Label-free & $50 \mathrm{pM}-100 \mathrm{nM}$ & $1.45 \mathrm{pM}$ & $45 \mathrm{~min}$ & 4 \\
\hline $\begin{array}{l}\text { Graphene screen- } \\
\text { printed electrode }\end{array}$ & $\begin{array}{l}\text { SWV with quasi- } \\
\text { steady flow }\end{array}$ & acpcPNA & Label-free & $\begin{array}{c}10 \mathrm{pM}-2,000 \mathrm{nM}^{\mathrm{a}} \\
10^{2}-10^{6} \text { copies } \mu \mathrm{L}^{-1, \mathrm{~b}}\end{array}$ & $\begin{array}{c}7.23 \mathrm{pM}^{\mathrm{a}}, \\
1.13 \times 10^{1} \text { copies } \mu \mathrm{L}^{-1, \mathrm{~b}}\end{array}$ & $7 \mathrm{~min}$ & $\begin{array}{l}\text { This } \\
\text { work }\end{array}$ \\
\hline
\end{tabular}




\section{Synthesis of acpcPNA Probe}

For the synthesis of the acpcPNA probe, L-Lysinamide was incorporated at the C-terminus to improve the aqueous solubility and reduce aggregation. After completion of the synthesis, the $N$-terminal Fmoc group was removed and capped by acetylation. The sidechain protecting groups of the nucleobases $\mathrm{A}$ and $\mathrm{C}(\mathrm{Bz})$ were removed by treatment with 1:1 ammoniadioxane at $65{ }^{\circ} \mathrm{C}$ overnight. The PNA was cleaved from the solid support by treatment with trifluoroacetic acid (TFA) (500 $\mu \mathrm{L}, 30 \mathrm{~min} \times 3$ ). The cleavage solution was combined and dried under a stream of nitrogen. The crude acpcPNA was precipitated by the addition of diethyl ether and purified by reverse-phase HPLC using a Water Delta $600^{\mathrm{TM}}$ system utilizing a $\mathrm{C} 18$ column and $0.1 \% \mathrm{v} / \mathrm{v}$ TFA in an $\mathrm{H}_{2} \mathrm{O}-\mathrm{MeOH}$ gradient. The identity of the acpcPNA was confirmed by MALDI-TOF MS analysis by a Microflex MALDI-TOF mass spectrometer (Bruker Daltonics), employing $\alpha$-cyano-4-hydroxycinnamic acid (CCA) as a matrix $(\mathrm{m} / \mathrm{z}$ calcd. for $\mathrm{M} \cdot \mathrm{H}+=5304.7$, found 5305.3) (Figure $\mathrm{S} 1)$, and by $T_{\mathrm{m}}$ experiments $\left(T_{\mathrm{m}}\right.$ with complementary DNA $>85^{\circ} \mathrm{C}$, at $1 \mu \mathrm{M}$ PNA and DNA in $10 \mathrm{mM}$ sodium phosphate buffer $\mathrm{pH} 7.0$ containing $100 \mathrm{mM}$ $\mathrm{NaCl}$ ). The purity was confirmed to be $>90 \%$ by reverse-phase HPLC (Figure S2).

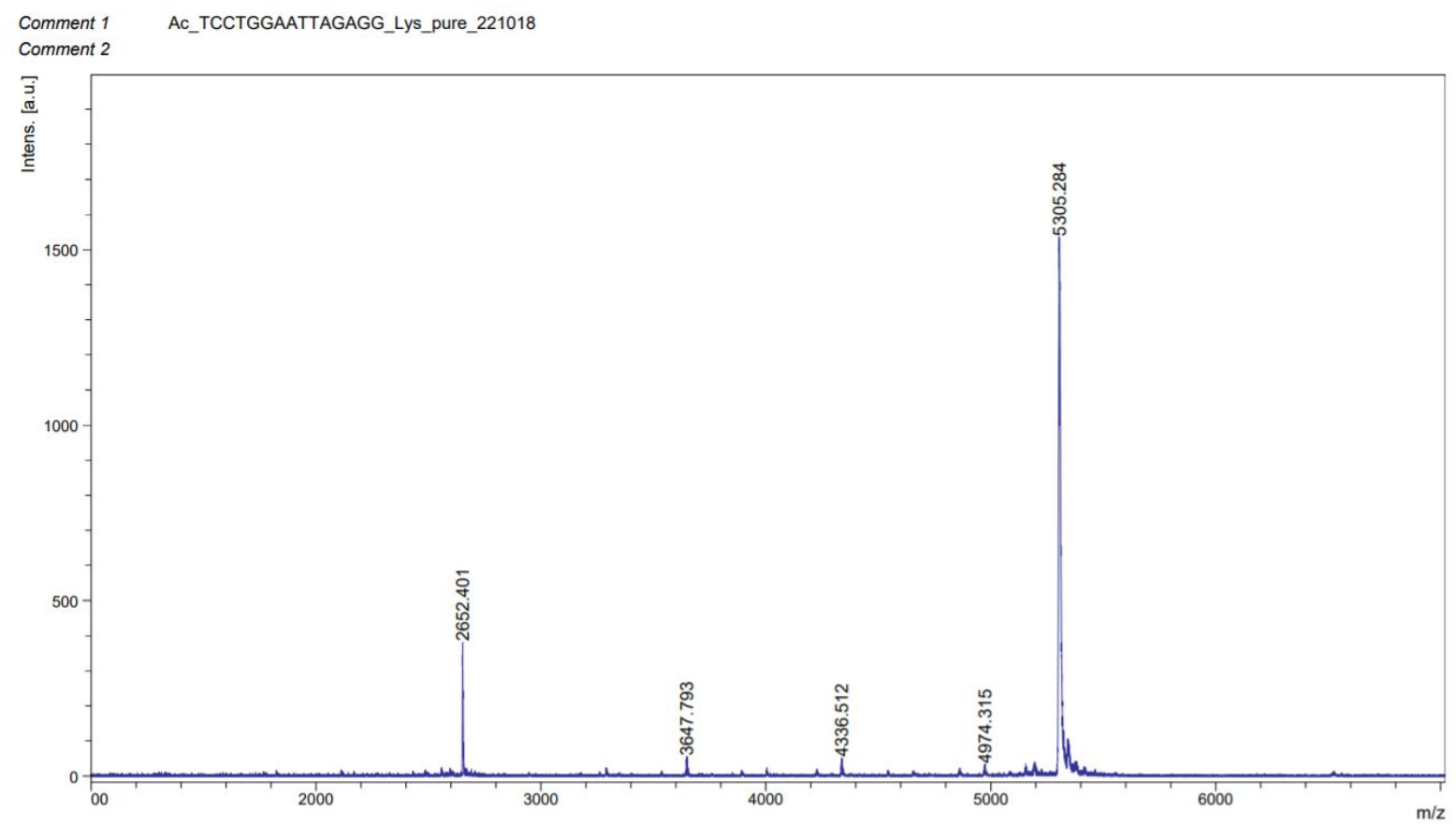

Figure S1. Mass spectrum of the acpcPNA 


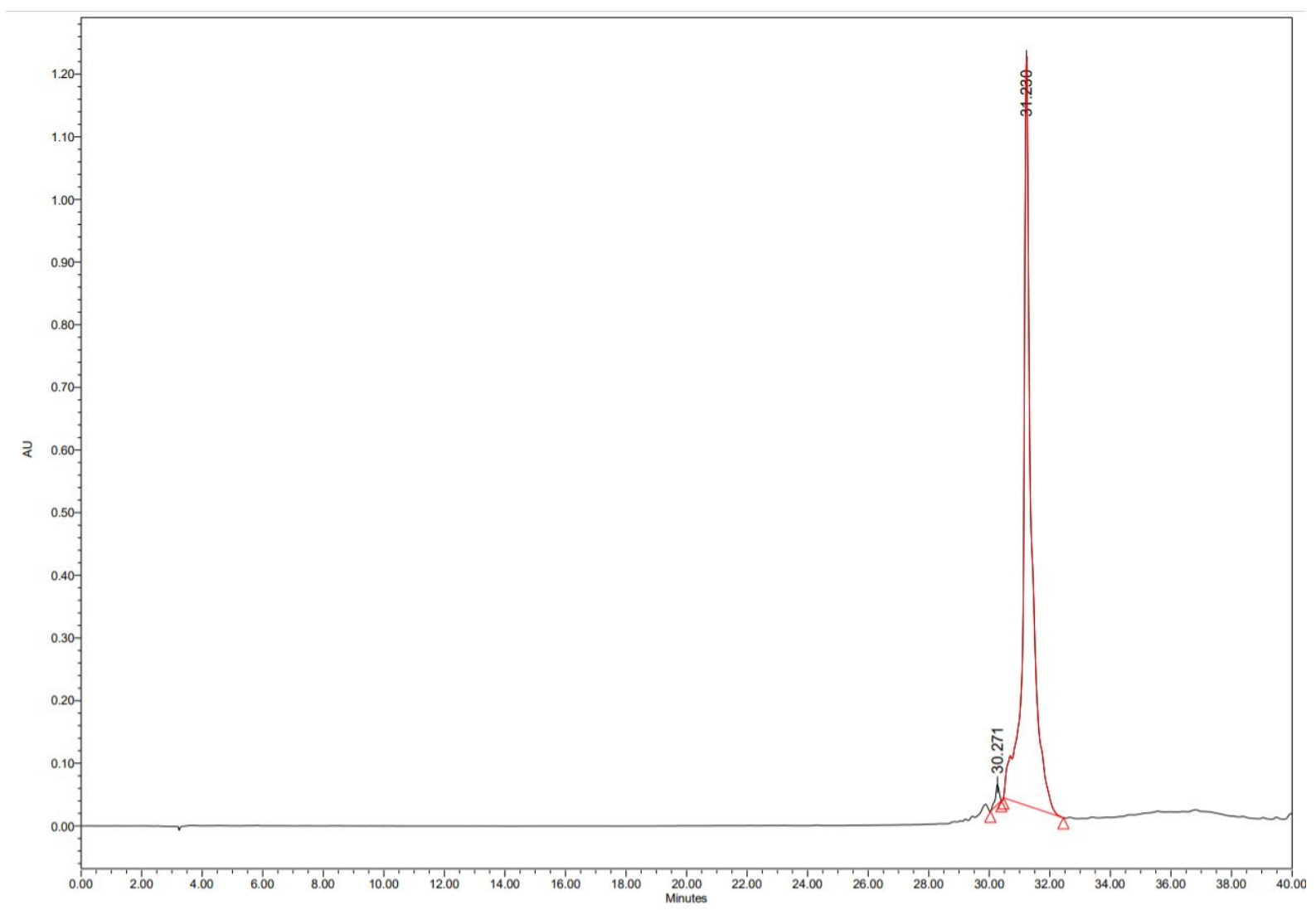

Figure S2. Chromatogram for confirming the purity of acpcPNA

\section{Materials, Equipment, and Chemicals}

All reagents were of analytical grade. L-Ascorbic acid $\left(\mathrm{C}_{6} \mathrm{H}_{8} \mathrm{O}_{6}\right)$ was produced from Carlo Erba reagents (Lombardy, Italy). Methylene blue $\left(\mathrm{C}_{16} \mathrm{H}_{18} \mathrm{ClN}_{3} \mathrm{~S} .2 \mathrm{H}_{2} \mathrm{O}\right)$ was obtained from UNILAB ${ }^{\circledR}$ Laboratory Reagents (Geneva, Switzerland). Phosphate buffer saline pH 7.4 ([NaCl]: $\left.137 \mathrm{mM},[\mathrm{KCl}]: 2.7 \mathrm{mM},\left[\mathrm{Na}_{2} \mathrm{HPO}_{4}\right]: 10 \mathrm{mM},\left[\mathrm{KH}_{2} \mathrm{PO}_{4}\right]: 1.8 \mathrm{mM}\right)$ was acquired from Merck (Darmstadt, Germany). Standard gold solution $(1000 \mathrm{mg} \mathrm{L}-1)$ for AAS, Tween-20 $\left(\mathrm{C}_{58} \mathrm{H}_{114} \mathrm{O}_{26}\right)$, sodium dodecyl

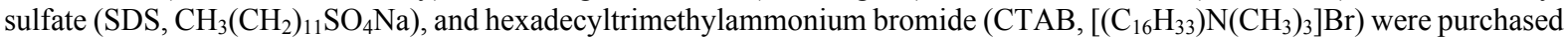
from Sigma-Aldrich (St. Louis, United States). All aqueous solutions were freshly prepared in ultrapure water produced using a Milli-Q system $(18 \mathrm{M} \Omega \bullet \cdot \mathrm{cm})$ purchased from Millipore.

Carbon graphene ink and silver ink were obtained from Serve Science Company Limited (Bangkok, Thailand) and Gwent Group (Torfaen, United Kingdom), respectively. The screen-printed templates were made by Chaiyaboon Co., Ltd. (Bangkok, Thailand). Nitrocellulose membrane (AE99), sample pad (FUSION 5), and absorbent pad (CF7) were purchased from Whatman-GE Healthcare (Pittsburgh, USA).

All synthetic oligonucleotides were purchased from Pacific Science (Bangkok, Thailand). The base sequences are shown in Table S1. All DNA stock solutions were prepared using PBS buffer solution (1x PBS, pH 7.4) and kept at $-20^{\circ} \mathrm{C}$ and diluted with $0.5 \% \mathrm{w} / \mathrm{v}$ SDS in PBS buffer prior to use.

All electrochemical measurements were performed using a PalmSens 4 potentiostat/impedance analyzer (PalmSens BV, Netherlands).

\section{Serum Extraction of HBV DNA using phenol-chloroform-isoamyl alcohol method}

Briefly, $200 \mu \mathrm{L}$ of the serum was incubated with $400 \mu \mathrm{L}$ of lysis buffer (10 mM Tris-HCl, pH 8.0) and $10 \mu \mathrm{L}$ of proteinase $\mathrm{K}$ (Life Technologies, USA) at $50^{\circ} \mathrm{C}$ for 1 hour. Then, $250 \mu \mathrm{L}$ of phenol and $250 \mu \mathrm{L}$ of chloroform:isoamyl alcohol (49:1) were added and centrifuged at $13,500 \mathrm{rpm}$ and $4^{\circ} \mathrm{C}$ for $40 \mathrm{~min}$. After centrifugation, the aqueous phase was transferred to a new microcentrifuge tube. To this solution, $4 \mu \mathrm{L}$ of glycogen, $800 \mu \mathrm{L}$ of absolute ethanol, and $40 \mu \mathrm{L}$ of $2 \mathrm{M}$ sodium acetate $(\mathrm{NaOAc})$ were added. The solution was mixed well by inversion and incubated at $-70^{\circ} \mathrm{C}$ for $30 \mathrm{~min}$. Next, the sample was centrifuged at $13,500 \mathrm{rpm}$ and $4^{\circ} \mathrm{C}$ for $30 \mathrm{~min}$, the supernatant was discarded, and the washed pellet was resuspended in $1 \mathrm{~mL}$ of $70 \%$ ethanol at RT for $5 \mathrm{~min}$. After that, the samples were centrifuged again at $14,000 \mathrm{rpm}$ and $4^{\circ} \mathrm{C}$ for $5 \mathrm{~min}$. The supernatant was discarded, and the pellet was dried for $15 \mathrm{~min}$ at RT. Finally, $30 \mu \mathrm{L}$ of sterile distilled water was added to dissolve the DNA pellet to give a solution that was immediately stored at $-20^{\circ} \mathrm{C}$ until further analysis. 


\section{Plasmid constructs HBV DNA preparation}

The pUC19 vector carrying 1.24 fold the HBV genome (nucleotide numbered according to the prototype HBV/C clone with accession no. NC_003977) were transformed and propagated in competent Escherichia coli cells (DH5 ). Then plasmid-transfected E. coli was plated on LB agar containing antibiotic and incubated for $16 \mathrm{hrs}$. The blue colony was selected and cultured in LB broth overnight. The plasmid-transfected $E$. coli cells were extracted for DNA by using a DNA extraction kit (RabbitBiotech, Germany). The extracted DNA was stored at $-8{ }^{\circ} \mathrm{C}$ until further analysis. The HBV DNA sequence in the extracted DNA was confirmed by using the DNA Sequencing Service at 1st Base Company, Singapore.

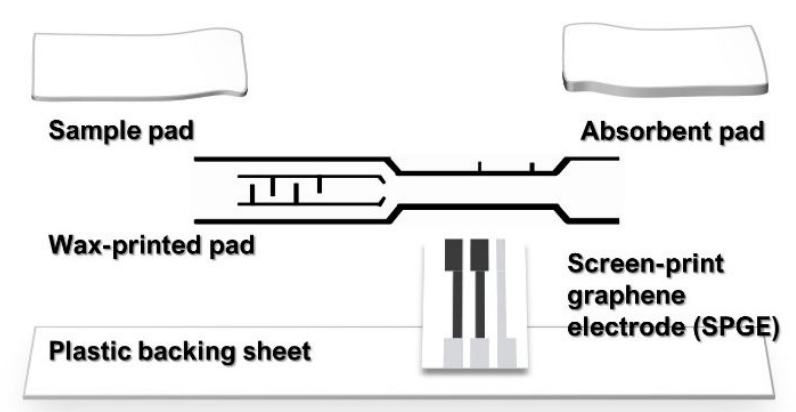

Figure S3. Component of the automated paper-based lateral flow device.

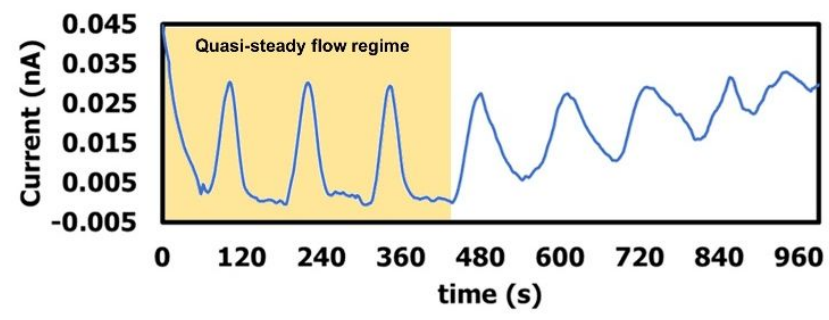

Figure S4. Amperometric response of ascorbic acid

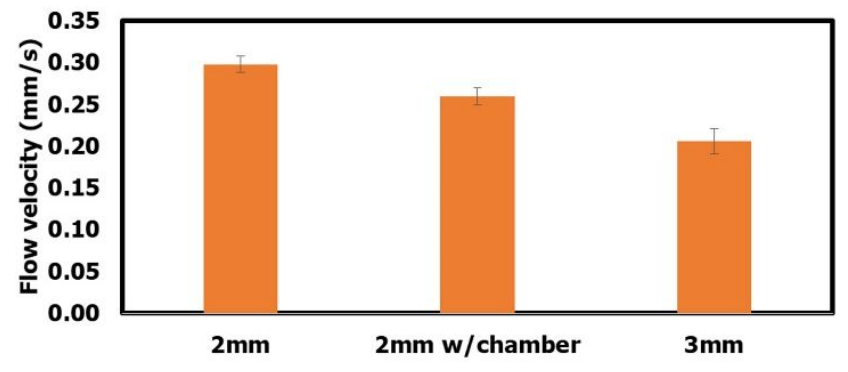

Figure S5. Flow velocity at different channel widths 

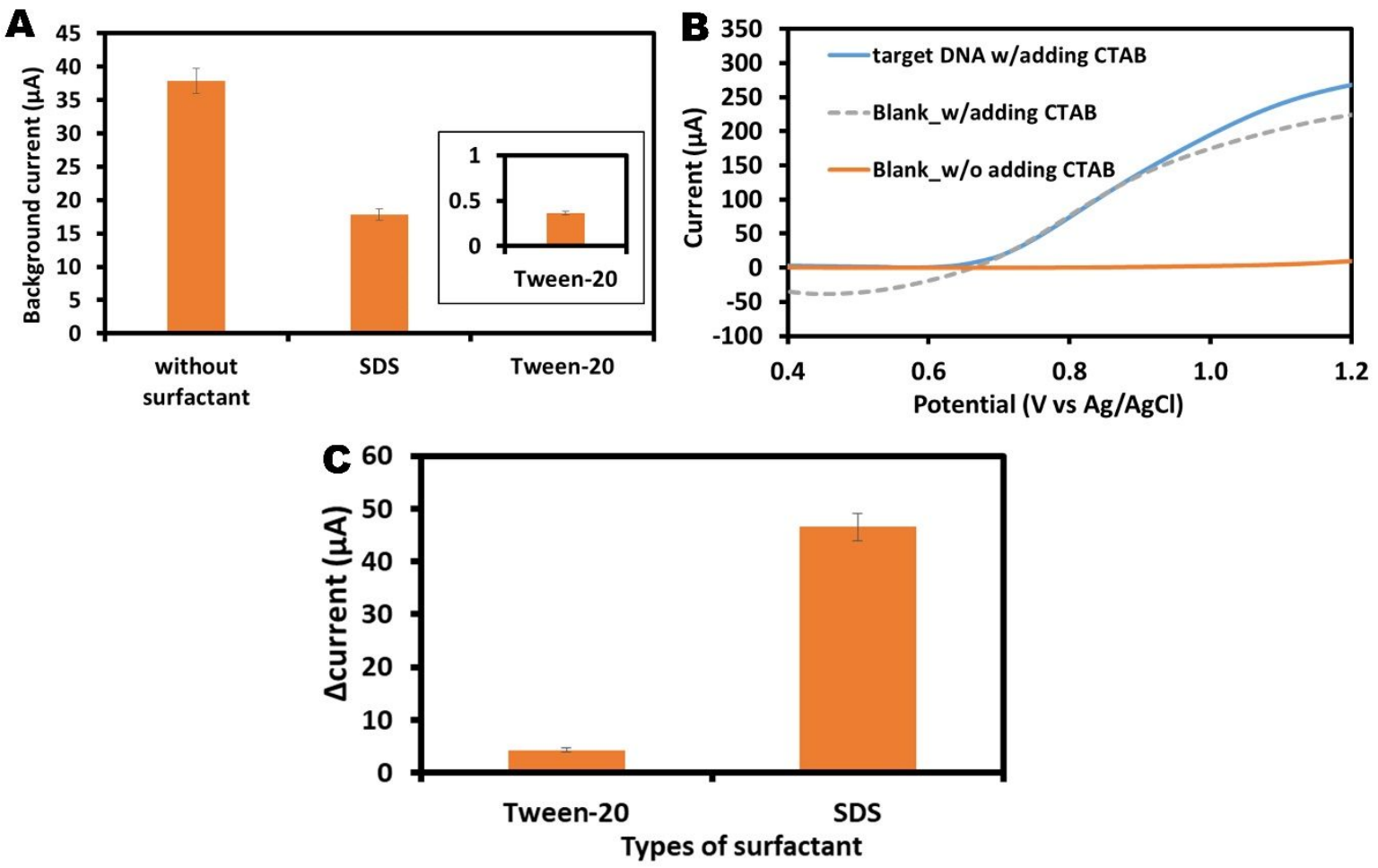

Figure S6. The effect of type of surfactants (A) the background current of the system without surfactant, with SDS, and with Tween-20. (B) Square-wave voltammograms of the system with CTAB (C) differential current of the system with different type of surfactants

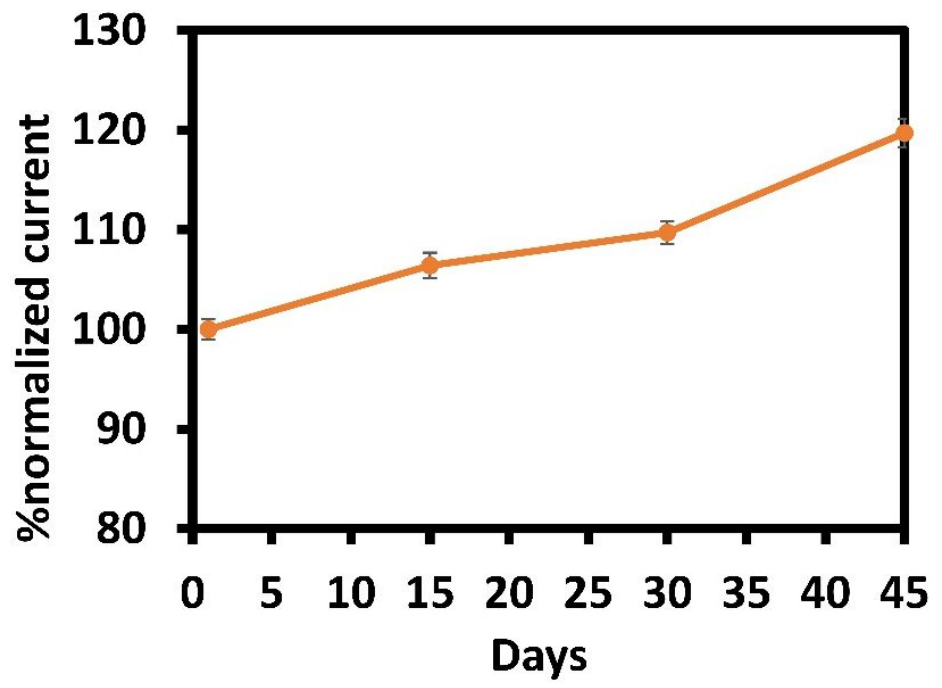

Figure S7. Stability of automated eFLA device. Error bars indicate the standard deviation of flow velocity from threeindependent devices $(n=3)$. 


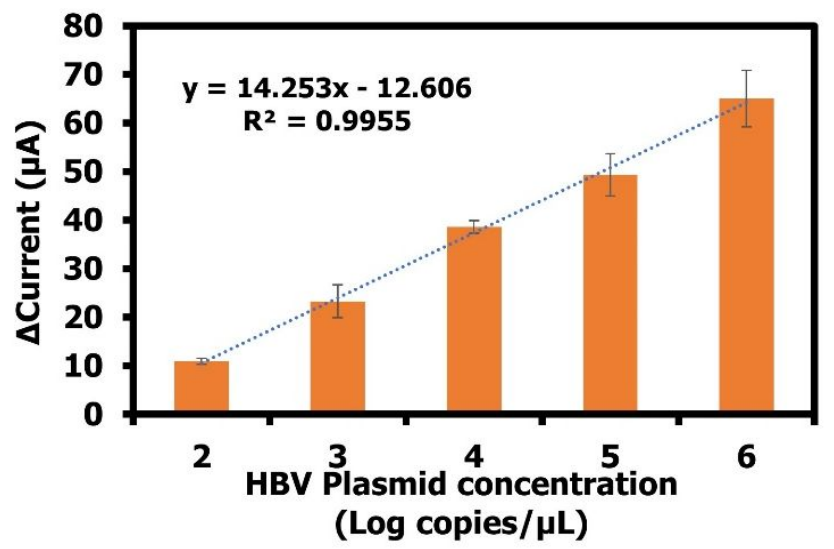

Figure S8. The feasibility of the proposed device with the HBV DNA plasmid constructs. A bar graph shows the differential current responses of the plasmid constructs, ranging from $2.82 \times 10^{2}$ to $2.82 \times 10^{6}$ copies $\mu \mathrm{L}^{-1}(\mathrm{n}=3)$. 


\section{References}

1. $\quad \mathrm{Li}, \mathrm{X}$.; Scida, K.; Crooks, R. M., Detection of Hepatitis B Virus DNA with a Paper Electrochemical Sensor. Analytical Chemistry 2015, 87 (17), 9009-9015.

2. Zhao, F.; Bai, Y.; Cao, L.; Han, G.; Fang, C.; Wei, S.; Chen, Z., New electrochemical DNA sensor based on nanoflowers of Cu3(PO4)2-BSA-GO for hepatitis B virus DNA detection. Journal of Electroanalytical Chemistry 2020, 867, 114184.

3. Xiang, Q.; Huang, J.; Huang, H.; Mao, W.; Ye, Z., A label-free electrochemical platform for the highly sensitive detection of hepatitis B virus DNA using graphene quantum dots. RSC advances 2018, 8 (4), 1820-1825.

4. $\quad$ Srisomwat, C.; Teengam, P.; Chuaypen, N.; Tangkijvanich, P.; Vilaivan, T.; Chailapakul, O., Pop-up paper electrochemical device for label-free hepatitis B virus DNA detection. Sensors and Actuators B: Chemical 2020, 316, 128077. 